\title{
Sports training in taekwondo WTF LMAI (locomotor apparatus injury) on the basis of inclusive education
}

\author{
Yevgeny Golovikhin ${ }^{1}$, Olga Razumova ${ }^{2 *}$, Yuriy Zhuykov ${ }^{3}$, Alexey Kaplev ${ }^{4}$ \\ ${ }^{1}$ Sports School Named After D.A. Razumovskiy, 432046, Ulyanovsk, Russia \\ ${ }^{2}$ Ulyanovsk State Agrarian University Named After P.A. Stolypin, 432029, Ulyanovsk, Russia \\ ${ }^{3}$ Russian State University of Physical Culture, Sport, Youth and Tourism, 105122, Moscow, Russia \\ ${ }^{4}$ Volga Region State Academy of Physical Culture, Sport and Tourism, 420010, Kazan, Russia
}

\begin{abstract}
Nowadays in a new Paralympic kind of sport taekwondo WTF LMAI in Russia there is no Federal State Educational Standard (FSES). Athletes-invalids train in terms of standard for people with LMAI (locomotor apparatus injury) or taekwondo standard in the groups with healthy athletes. For the detailed study of the educational-training process with Paralympic taekwondo-athletes it is necessary to create effective technologies, define the methods of work. The aim of the work is to substantiate educational-training process in taekwondo for people with locomotor apparatus injury. The introduced practice of inclusive methods of teaching on the scientific base helped to achieve high stable result. We proved the necessity to realize cooperative lessons of taekwondo-athletes with LMAI and healthy, specially trained for them, taekwondo-athletes. We defined prospective directions in inclusive teaching Paralympic kind of sport taekwondo WTF LMAI.
\end{abstract}

\section{Introduction}

In 2013 the program of Paralympic Games 2020 for the first time included a new kind of sport for invalids of taekwondo WTF LMAI, the international notion is parataekwondo. Two units: K-43 and K-44 were included into Paralympic program. According to the rating of the gathered points the first four numbers in three weight categories among men $(61 \mathrm{~kg}, 75 \mathrm{~kg}$ and more than $75 \mathrm{~kg})$ and in three weight categories among women $(49 \mathrm{~kg}, 58 \mathrm{~kg}$ and more than $58 \mathrm{~kg}$ ) were selected for Paralympic Games. The rest of the athletes would be selected during continental tournaments, taking the first-second place. For the first time International taekwondo WTF LMAI competitions were held in 2009 in Baku, Azerbaijan, where the Russian athletes took part. For the first time the World Champion became Russian athlete Artur Kan.

Taekwondo use as the means of psychic and physical rehabilitation of children-invalids with the upper extremities injury by means of taekwondo was considered in 2007 by Pavlenko A.V. Taekwondo WTF LMAI coach Golovikhin E.V. since 2010 studied and used inclusive education in Russian parataekwondo. The organized experimental platform by the collective of specialists helped to study the peculiarities of stage preparation of the Olympic cycle among taekwondo-athletes with LMAI.

In 2011 for the first time national parataekwondo team of Russia was formed. It included the athletes from KhantyMansiysk Autonomous District- Yugra, Dagestan, Tver, the Republic of North Ossetia-Alania.

The work was supported by specialists-coaches from different regions of Russia, who needed special technologies and methodologies of sports lessons organization.

Insufficient amount of scientific-methodical literature concerning taekwondo WTF LMAI and the absence of FSES prevent the development of this kind of sport and demand detailed attention paid to the methodology and scientific substantiation of training technologies and methods.

Scientific validity of educational-training process organization with the planned result of selection for Paralympic Games in Tokyo 2020, taking into account possible and effective resources is urgent and timely for the Olympic cycle of training 2016-2019.

This forms the urgency of the research.

The aim of the research is to create sports training in taekwondo WTF LMAI on the basis of inclusive education, taking into account competitive actions.

Hypothesis of the research: a scientific approach on the basis of inclusive education to educational-training process organization would allow the following:

- To make a qualitative analysis of competitive actions estimation in the combat of the Russian and the International parataekwondo athletes;

- The revealed peculiarities of parataekwondo athletes sports training during the training lessons and competitions would correct educational-training process. It would influence the results of an athlete; 
- The research results would help in methodical support of educational-training process during training coachesteachers in taekwondo WTF LMAI;

- To prepare athletes with LMAI in taekwondo WTF LMAI for successful starts of the selective Olympic cycle 2016-2020 and go through the selection for Paralympic Games in Tokyo 2021.

Scientific significance is in scientific substantiation of the author's approach to inclusive education of parataekwondo athletes.

Practical importance of the work would help to use the research results in real practice of educational-training lessons of teaching taekwondo WTF LMAI.

During the practical work we revealed the necessity to use cooperative training lessons of healthy athletes and taekwondo athletes with LMAI.

As there is no FSES in this kind of sport, the directors of the state sports establishments regulated the work on the basis of the existing theses for the work with the athletes with LMAI and healthy athletes.

In terms of such demands we took into the group of healthy athletes the athlete-invalid. He received medical allowance in order to train on equal bases. It was impossible to form the separate group of invalids.

Special rules of competitions were created in accordance with anatomic and physiological disorders in the upper extremities. The difference in the rules of competitions for healthy athletes was the prohibition of the attack using a kick on the head. Only attacking actions into the zone of body were allowed.

A coach should understand the difference in sports training of healthy taekwondo athletes and parataekwondo athletes. The technique and tactics of combat differed significantly.

\section{Results and discussion}

In order to train athletes-partners we used technical-tactical characteristics of healthy athletes. In the experiment with parataekwondo athletes we analyzed technical-tactical characteristics of the athletes with LMAI.

The research works were held since September, 2010-till April, 2018 on the basis of sports teams of KhantyMansiysk Autonomous District- Yugra, Dagestan, Ulyanovsk, national teams of Russia.

The athletes of the $1^{\text {st }}$ category and higher took part in the research. In general 50 combats were analyzed. All athletes were men at the age of 18-32. The weight of the respondents was from 61 to $110 \mathrm{~kg}$. Two groups were created for the experiment: control group and experimental group. Each group included 8 athletes. The control group included 8 athletes-invalids. They presented the following groups: K- 42, K- 43, K- 44. The athletes had the experience of taking part in competitions. The age of athletes was from 18 to 36 years old. All athletes trained in sections with healthy athletes [1]. They trained according to the programs of training athletes of sports improvement groups. The control group included taekwondo athletes with LMAI from different regions of Russia. They were always in contact and whose competitive combats could be regularly analyzed.

The experimental group included 8 athletes-invalids. Parataekwondo athletes presented the group: K- 43, K- 44.The age of athletes was from 22 to 34 years old. All athletes had the experience of taking part in the competitions.

Since September, 2010 till December, 2018 there was combats analysis in taekwondo athletes with LMAI. All examined respondents trained according to their individual plans.

In December, 2010 according to the results of the research we formed the experimental group from two taekwondo athletes with LMAI.

In the experimental group the lessons were held according to the created by us methodology, taking into account the results of the research on the basis of inclusion.

In the control group the lessons were held according to generally adopted methodology (narration, demonstration, technical and tactical techniques fulfillment).

During the experiment we worked on the use of tactical-technical peculiarities of a competitive combat organization. The base of the experimental group athletes-invalids training formed model demands claimed on the main parameters of the kind of sport. In accordance with the research works of native and foreign specialists, the summarized model of the strongest athletes provides four levels depending on their subordinated relations.

The first level of the model considers the indices of physical, technical training. With the possibility to train and develop the skills of technical-tactical actions on the basis of qualitative motor-coordinating base and the corresponding level of physical readiness of each athlete.

At the second level the characteristics of competitive activity are considered. They are defined as a result of a longterm information gathering during the competitions.

At the third level the characteristics of athletes' physical, technical and tactical readiness during the period of their best fitness are considered.

At the fourth level we see the characteristics of functional and psychological readiness, morphological peculiarities, age and sports experience of athletes during the period of their highest sports achievements [4,5,6].

After the pedagogical experiment, which lasted till April 2020, in order to estimate the effectiveness of the pedagogical influences we held additional examination of tactical-technical actions indices during the competitive sparring.

During the process the following differences were revealed:

1. The distance of kicking. Competitive technique and tactics in taekwondo and taekwondo WTF LMAI differ significantly. The prohibition of the attacking the head almost prevents the attacks from close distance. 
2. Movements in steps.

3. Kicks in parataekwondo are stronger. Because of smaller estimating zone. Many attacking actions with the far leg.

4. The absence of hand hit estimation in parataekwondo. Judges don't give points for a hand hit, as a hand hit can harm the opponent in terms of competitive rules.

5. Motor density of the combat. The density of the combat in parataekwondo is higher. The amount of the attacking blows is higher.

6. The defensive actions. The average level is the zone of defense, which helps to fulfill tactical techniques. There are less tactical techniques during the attacks into the body.

7. The blows estimations in points are lower, than in usual taekwondo.

Competitive activity estimation in healthy taekwondo athletes helped to fulfill comparative analysis with competitive activity estimation in taekwondo athletes with LMAI [3].

We examined the combats at Parataekwondo World Championships 2017 in London, Europe Championships 2017 and 2018 in Bulgaria at Taekwondo World Championships 2015 in Chelyabinsk (Russia), 2017 in Muju (South Korea). During the research there appeared the material for comparison and analysis. It helped to define and continue further prospects of inclusive education in taekwondo WTF LMAI. The information is presented in table 1.

Table 1. The amount of tactical-technical actions in competitive practice of taekwondo athletes and taekwondo athletes with LMAI

\begin{tabular}{|c|c|c|c|c|c|c|c|c|c|c|c|c|c|}
\hline \multirow[t]{3}{*}{ № } & \multirow{3}{*}{$\begin{array}{l}\text { Tactical-technical actions of } \\
\text { taekwondo athletes and } \\
\text { parataekwondo athletes in a combat }\end{array}$} & \multicolumn{4}{|c|}{ General amount of actions } & \multicolumn{4}{|c|}{ Volume in \% } & \multicolumn{4}{|c|}{ Effect in \% } \\
\hline & & \multicolumn{2}{|c|}{$\begin{array}{l}\text { Taekwondo } \\
\text { athletes }\end{array}$} & \multicolumn{2}{|c|}{$\begin{array}{l}\text { Experiment } \\
\text { al group }\end{array}$} & \multicolumn{2}{|c|}{$\begin{array}{l}\text { Taekwondo } \\
\text { athletes }\end{array}$} & \multicolumn{2}{|c|}{$\begin{array}{l}\text { Experiment } \\
\text { al group }\end{array}$} & \multicolumn{2}{|c|}{$\begin{array}{l}\text { Taekwondo } \\
\text { athletes }\end{array}$} & \multicolumn{2}{|c|}{$\begin{array}{l}\text { Experiment } \\
\text { al group }\end{array}$} \\
\hline & & $\begin{array}{l}\text { befo } \\
\text { re }\end{array}$ & after & $\begin{array}{l}\text { befo } \\
\text { re }\end{array}$ & $\begin{array}{l}\text { afte } \\
\mathrm{r}\end{array}$ & $\begin{array}{l}\text { befo } \\
\text { re }\end{array}$ & after & $\begin{array}{l}\text { befo } \\
\text { re }\end{array}$ & after & $\begin{array}{l}\text { befo } \\
\text { re }\end{array}$ & after & $\begin{array}{l}\text { befo } \\
\text { re }\end{array}$ & after \\
\hline 1. & Attack imitation & 152 & 152 & 107 & 121 & 14,6 & 14,6 & 14,6 & 14,6 & - & - & 8 & 12 \\
\hline 2. & Attack with a single movement & 195 & 195 & 175 & 178 & 5,7 & 5,7 & 8,7 & 9,7 & 15 & 14 & 15,5 & 18,5 \\
\hline 3. & $\begin{array}{l}\text { Opponent provocation to fulfill } \\
\text { premature maneuver and counterattack }\end{array}$ & 89 & 89 & 67 & 87 & 9 & 10,6 & 10,6 & 10,6 & 5,6 & 5,6 & 5,6 & 7,8 \\
\hline 4. & $\begin{array}{l}\text { Opponent provocation to fulfill } \\
\text { premature hit and counterattack }\end{array}$ & 98 & 98 & 38 & 43 & 6,4 & 6,4 & 6,4 & 6,4 & 3,2 & 3,2 & 3,2 & 6 \\
\hline 5. & Defense from the standing attack & 56 & 56 & 26 & 33 & 0,7 & 0,7 & 0,7 & 0,7 & 67 & 67 & 67 & 9 \\
\hline 6. & Defense from the attack during retreat & 78 & 78 & 71 & 75 & 1,5 & 1,5 & 1,5 & 1,5 & 81 & 81 & 81 & 88 \\
\hline 7. & Defense imitation & 44 & 44 & 22 & 20 & 0,9 & 0,9 & 0,9 & 0,9 & 4 & 4,3 & 4,2 & 6,3 \\
\hline 8. & The use of opponent's attack end & 51 & 51 & 10 & 32 & 5,4 & 5,4 & 5,4 & 5,4 & 4,4 & 4,4 & 4,4 & 5 \\
\hline 9. & $\begin{array}{l}\text { Attack during the opponent's leg } \\
\text { placing after the hit }\end{array}$ & 76 & 76 & 52 & 65 & 6,7 & 6,7 & 6,7 & 6,7 & 5,1 & 5,1 & 5,1 & 7 \\
\hline 10. & Attack after the block from the hit & 34 & 34 & 23 & 33 & 3,2 & 3,2 & 3,2 & 3,2 & 3 & 3 & 3 & 6 \\
\hline 11. & Front hand attack & 8 & 8 & - & - & 1,3 & 1,3 & - & - & - & - & - & - \\
\hline 12. & $\begin{array}{l}\text { Provocation to fulfill the attack by } \\
\text { means of hit surface opening }\end{array}$ & 79 & 79 & 45 & 65 & 6,8 & 6,8 & 6,8 & 6,8 & 8 & 8 & 8 & 11 \\
\hline 13. & Attack with the combinations & 43 & 43 & 26 & 47 & 0,9 & 0,9 & 0,9 & 0,9 & 34 & 34 & 34 & 52 \\
\hline 14. & $\begin{array}{l}\text { Provoking by dangerous distance } \\
\text { entrance }\end{array}$ & 122 & 122 & 72 & 84 & 11,2 & 11,2 & 11,2 & 11,2 & 11,3 & 11,3 & 11,3 & 14 \\
\hline 15. & Mush after the blow & 67 & 67 & 43 & 44 & 7,9 & 7,9 & 7,9 & 7,9 & 7,8 & 7,8 & 7,8 & 9,1 \\
\hline 16. & Blows exchange & 88 & 88 & 35 & 28 & 5,5 & 5,5 & 5,5 & 5,5 & 31,1 & 31,1 & 31,1 & 34 \\
\hline & Total: & $\begin{array}{l}165 \\
2\end{array}$ & $\begin{array}{l}165 \\
2\end{array}$ & 658 & 778 & 100 & 100 & 100 & 100 & & & & \\
\hline
\end{tabular}

Attacking from the standing position (frequency of use $-18,5 \%$, general effectiveness- $2,3 \%$ ) is mainly realized by means of "dolleo chagi" and "pada chagi" blows, more seldom by means of "nerio chagi" blow. As the contact of foot with the electronic vest is estimated in taekwondo, the blow should be quick during the blows on the body. The success of the hits in combat is provided owing to the threat of the blow start, provoking the opponent for counterattacks fulfillment. Beating the opponent was realized at the level of making and canceling the decision to realize the action. Attacking by series (frequency of use - 2,3\%, general effectiveness- 0,3\%) the combatants mainly realize with the help of blows "pada chagi" and "dolleo chagi". Series of two blows prevail. Also athletes fulfill mutual series and series after the opponent's attack. The series of blows fulfillment makes the opponent react, which during several successive blows fulfillment increases the chances to get the point $[2,4]$.

Then we studied model characteristics of competitive activity estimation in athletes-invalids in two groups: control group and experimental group. Parataekwondo athletes from the experimental group trained according to the author's methodology on the basis of inclusive method of the training process organization. Table 2 shows technical-tactical actions analysis among parataekwondo athletes from the control and the experimental groups.

Table 2. The amount of tactical-technical actions in competitive practice of taekwondo athletes with LMAI $(n=24)$, amount of combats 50 


\begin{tabular}{|c|c|c|c|c|c|c|c|c|c|c|c|c|c|}
\hline \multirow[t]{3}{*}{ № } & \multirow{3}{*}{ 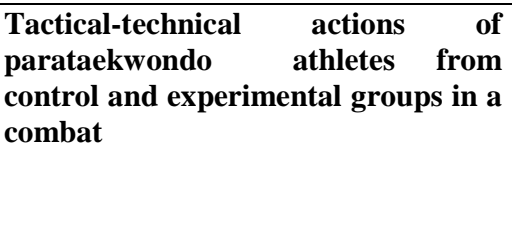 } & \multicolumn{4}{|c|}{ General amount of actions } & \multicolumn{4}{|c|}{ Volume in \% } & \multicolumn{4}{|c|}{ Effect in \% } \\
\hline & & \multicolumn{2}{|c|}{$\begin{array}{l}\text { Control } \\
\text { group }\end{array}$} & \multicolumn{2}{|c|}{$\begin{array}{l}\text { Experiment } \\
\text { al group }\end{array}$} & \multicolumn{2}{|c|}{$\begin{array}{l}\text { Control } \\
\text { group }\end{array}$} & \multicolumn{2}{|c|}{$\begin{array}{l}\text { Experiment } \\
\text { al group }\end{array}$} & \multicolumn{2}{|c|}{$\begin{array}{l}\text { Control } \\
\text { group }\end{array}$} & \multicolumn{2}{|c|}{$\begin{array}{l}\text { Experiment } \\
\text { al group }\end{array}$} \\
\hline & & $\begin{array}{l}\text { befo } \\
\text { re }\end{array}$ & after & $\begin{array}{l}\text { befo } \\
\text { re }\end{array}$ & $\begin{array}{l}\text { afte } \\
\mathrm{r}\end{array}$ & $\begin{array}{l}\text { befo } \\
\text { re }\end{array}$ & after & $\begin{array}{l}\text { befo } \\
\text { re }\end{array}$ & after & $\begin{array}{l}\text { befo } \\
\text { re }\end{array}$ & after & $\begin{array}{l}\text { befo } \\
\text { re }\end{array}$ & after \\
\hline 1. & Movements with the attack start & 145 & 146 & 143 & 161 & 18 & 18 & 16,2 & 17,1 & 5 & 5 & 9 & 14 \\
\hline 2. & Attack imitation & 151 & 152 & 107 & 121 & 14,6 & 14,6 & 14,6 & 14,6 & 1 & 2 & 3 & 12 \\
\hline 3. & Attack with a single movement & 195 & 195 & 175 & 188 & 5,7 & 5,7 & 6,7 & 9,9 & 15 & 14 & 15,5 & 22,5 \\
\hline 4. & $\begin{array}{l}\text { Opponent provocation to fulfill } \\
\text { premature maneuver and counterattack }\end{array}$ & 87 & 89 & 86 & 112 & 9 & 10,6 & 10,6 & 13,5 & 5,6 & 5,6 & 5,6 & 8,6 \\
\hline 5. & $\begin{array}{l}\text { Opponent provocation to fulfill } \\
\text { premature hit and counterattack }\end{array}$ & 98 & 98 & 57 & 78 & 6,4 & 6,4 & 6,4 & 8,7 & 3,2 & 3,2 & 3,2 & 8,1 \\
\hline 6. & Defense from the standing attack & 56 & 56 & 66 & 78 & 0,7 & 0,7 & 0,7 & 0,7 & 67 & 67 & 67 & 9 \\
\hline 7. & Defense from the attack during retreat & 78 & 78 & 71 & 75 & 1,5 & 1,5 & 1,5 & 1,5 & 81 & 81 & 81 & 88 \\
\hline 8. & Defense imitation & 44 & 44 & 22 & 20 & 0,9 & 0,9 & 0,9 & 0,9 & 4 & 4,3 & 4,2 & 6,3 \\
\hline 9. & The use of opponent's attack end & 51 & 51 & 10 & 32 & 3,4 & 3.3 & 3,4 & 5,4 & 4,4 & 4,4 & 4,4 & 5,9 \\
\hline 10. & $\begin{array}{l}\text { Attack during the opponent's leg } \\
\text { placing after the hit }\end{array}$ & 76 & 76 & 52 & 65 & 6,7 & 6,7 & 6,7 & 6,7 & 5,1 & 5,1 & 5,1 & 7 \\
\hline 11. & Attack after the block from the hit & 34 & 34 & 23 & 33 & 3,2 & 3,2 & 3,2 & 3,2 & 3 & 3 & 3 & 6 \\
\hline 12. & $\begin{array}{l}\text { Provocation to fulfill the attack by } \\
\text { means of hit surface opening }\end{array}$ & 79 & 79 & 45 & 65 & 6,8 & 6,8 & 6,8 & 6,8 & 8 & 8 & 8 & 11 \\
\hline 13. & Attack with the combinations & 43 & 43 & 26 & 47 & 0,9 & 0,9 & 0,9 & 0,9 & 34 & 34 & 34 & 52 \\
\hline 14. & $\begin{array}{l}\text { Provoking by dangerous distance } \\
\text { entrance }\end{array}$ & 122 & 122 & 72 & 84 & 11,2 & 11,2 & 11,2 & 11,2 & 11,3 & 11,3 & 11,3 & 14 \\
\hline 15. & Mush after the blow & 67 & 67 & 43 & 44 & 7,9 & 7,9 & 7,9 & 7,9 & 7,8 & 7,8 & 7,8 & 9,1 \\
\hline 16. & Blows exchange & 88 & 88 & 35 & 28 & 5,5 & 5,5 & 5,5 & 5,5 & 31,1 & 31,1 & 31,1 & 34 \\
\hline & Total: & $\begin{array}{l}165 \\
2\end{array}$ & $\begin{array}{l}165 \\
2\end{array}$ & 658 & 778 & 100 & 100 & 100 & 100 & & & & \\
\hline
\end{tabular}

Analyzing the received results of the control and the experimental groups of athletes-invalids, who go in for parataekwondo, we see significant changes in the effectiveness of combats organization among athletes from the experimental group. The use of healthy athletes as the opponents helped to increase the level of tactical mastery of parataekwondo athletes from the experimental group. There is positive dynamics of 33,2\% at the exit control of the experiment in fulfilling the standards of competitive actions of a standing attack. The attacks after the defensive actions in the experimental group improved by $50 \%$. In the average positive dynamics of technical-tactical readiness results improvement in athletes-invalids from the experimental group is $27,4 \%$. In the control group there were no changes.

\section{Conclusions}

On the basis of the held research work we make the following conclusion:

1. Theoretical analysis of scientific-methodical literature revealed the forms and means of tactical-technical actions consideration among taekwondo athletes during competitive combat. We didn't find scientific-methodical literature concerning the questions of taekwondo sports training for people with LMAI.

2. Having studied the methodologies of teaching tactical-technical actions in competitive combat of taekwondo athletes with LMAI, revealed specific peculiarities for preparing inclusive education environment. It is a special training work for training sparring-partners, helpers from healthy athletes for an athlete-invalid in taekwondo WTF LMAI.

3. We defined the effectiveness of the offered methodology of inclusive teaching tactical-technical actions among taekwondo athletes with LMAI using small amount of respondents. It can lead to invalidation of the research. It is necessary to study more taekwondo athletes with LMAI.

4. Introduced into practice of work with taekwondo athletes with LMAI results of the experiment helped the respondents to win at Europe Championships 2017, 2018, 2019.

5. An athlete with LMAI should train separately according to own program, together with healthy athletes, who work with him as sparring partners and helpers. Mutual training lessons of an invalid in the group of healthy athletes according to FSES are less effective.

\section{References}

1. E.V. Golovikhin, Yu.Yu. Zhuykov, Taekwondo for people with LMAI (part of kerugi): educational-methodical manual (Ridero, Moscow, 2019)

2. A.S. Kuznetsov, Z.M. Kuznetsova, Russian Journal of Physical Education and Sport, 14(4), 5-7 (2019). DOI: 10.14526/20704798-2019-14-4-5-7 
3. E.V. Golovikhin, V.I. Vorobev, A.P. Efremov, A.V. Lashpanov, Peculiarities of taekwondo athletes' special motor and coordinating qualities formation (by the example of taekwondo national team of Russia): educational-methodical manual (STR (WTF), Moscow, 2007)

4. E.V. Golovikhin, Taekwondo program (WTF): program of sports training for educational establishments (sports schools for children and teen-agers, sports schools for children and teen-agers of the Olympic reserve, college of the Olympic reserve, federations, sport clubs and other juridical organizations of additional education) (STR (WTF), Moscow, 2007)

5. Yu.D. Zheleznyak, P.K. Petrov, Basis of scientific-methodical activity in physical culture and sport: manual for students of higher educational establishments (Moscow, 2001)

6. URL: http://www.paratkd.ru/ 